\title{
Structural variations among monocot emergent and amphibious species from lakes of the semi-arid region of Bahia, Brazil
}

\author{
Leite, KRB. ${ }^{\mathrm{a} *}$, França, $F^{\mathrm{b}}$ and Scatena, $V L .^{\mathrm{c}}$ \\ anstituto de Biologia, Universidade Federal da Bahia - UFBA, \\ Rua Barão de Jeremoabo, s/n, Campus Universitário de Ondina, CEP 40170-115, Salvador, BA, Brazil \\ bDepartamento de Ciências Biológicas, Universidade Estadual de Feira de Santana - UEFS, \\ BR 116, Km 03, Norte, Campus Universitário, CEP 44031-460, Feira de Santana, Bahia, Brazil \\ 'Departamento de Botânica, Instituto de Biociências, Universidade Estadual Paulista - UNESP, \\ CP 199, CEP 13506-900, Rio Claro, São Paulo, Brazil \\ *e-mail: kellyrbleite@gmail.com
}

Received November 12, 2010 - Accepted January 6, 2011 - Distributed February 29, 2012

(With 2 figures)

\begin{abstract}
Temporary lakes are common in the semi-arid region of the State of Bahia and form water mirrors in the rainy season. In this period, various vegetal species appear having different life forms adapted to the seasonality conditions of the rainfall regime. This work surveyed the adaptive anatomical structures of some emergent and amphibious monocot species occurring in these lakes. We studied the anatomy of roots, rhizomes, leaves and scapes of Cyperus odoratus, Oxycaryum cubense, Pycreus macrostachyos (Cyperaceae) - amphibious species; and of Echinodorus grandiflorus (Alismataceae), Eichhornia paniculata (Pontederiaceae) and Habenaria repens (Orchidaceae) - emergent species. The anatomical features of the dermal, fundamental and vascular systems confirming the tendency of the adaptive convergence of these plants to temporary lacustrine the environment include: single layered epidermal cells with a thin cuticle layer in the aerial organs; the presence of air canals in all the organs; few or no supporting tissues; and less numerous conducting elements and thinner cell walls in the xylem. The reduction of the supporting tissues, the number of stomata, which can even be absent, and the number of conducting elements and the degree of cell wall lignification in the xylem of the emergent species is more accentuated than that of the amphibious species. The pattern of distribution of aerenchyma in the roots of the studied species was considered important to distinguish between amphibious and emergent life forms.
\end{abstract}

Keywords: anatomy, monocotyledons, vegetative organs, temporary lakes.

\section{Variação estrutural entre espécies anfíbias e emergentes de monocotiledôneas de lagoas do semiárido da Bahia, Brasil}

\section{Resumo}

As lagoas temporárias são comuns no semiárido baiano, apresentando espelhos de água no período chuvoso. Nesse período, surgem várias espécies vegetais com diferentes formas de vida, adaptadas às condições de sazonalidade do regime pluviométrico. Este trabalho objetivou levantar estruturas anatômicas adaptativas de algumas espécies de monocotiledôneas anfíbias e emergentes que ocorrem nessas lagoas. Para tanto, estudou-se anatomia de raiz, rizoma, folha e escapo de Cyperus odoratus, Oxycaryum cubense e Pycreus macrostachyos (Cyperaceae) - anfíbias, e de Echinodorus grandiflorus (Alismataceae), Eichhornia paniculata (Pontederiaceae) e Habenaria repens (Orchidaceae) - emergentes. Características anatômicas dos sistemas dérmico, fundamental e vascular - presença de uma camada de células epidérmicas, com cutícula fina nos órgãos aéreos; presença de lacunas de ar em todos os órgãos; baixa quantidade ou ausência de tecidos de sustentação; redução de elementos xilemáticos e do espessamento das paredes de suas células - confirmam uma tendência à convergência adaptativa dessas plantas ao ambiente lacustre temporário. As espécies emergentes, quando comparadas com as espécies anfíbias, apresentam essas características mais acentuadas, como redução no sistema de sustentação; redução na frequência e até ausência de estômatos, e redução do número de elementos condutores do xilema e do grau de lignificação das paredes de suas células. O padrão de distribuição de aerênquima nas raízes das espécies estudadas foi considerado importante para distinguir a forma de vida anfíbia da forma emergente.

Palavras-chave: anatomia, monocotiledôneas, órgãos vegetativos, lagoas temporárias. 


\section{Introduction}

The Brazilian semi-arid region occupies about $900.000 \mathrm{~km}^{2}$ and it coincides with the areas of the caatinga vegetation (Eiten and Goodland, 1979; Queiroz et al., 2006). According to these authors, its climate presents an average annual precipitation of $800 \mathrm{~mm}$, irregular rains, which form temporary lakes in many Northeastern states.

Such lakes are characterized by the fact they are full in the wet season and empty during the dry spell. Their quantity of water depends on both their stocking capacity and the rainfall regime. This feature can be decisive for the establishment of aquatic macrophytes with different life forms, which prefer humidity within an environmental profile (Maltchik et al., 1999; Pivari et al., 2008).

Floristic surveys of aquatic macrophytes found in temporary lakes from the semi-arid region of Bahia showed that the most representative group is the monocots, especially Cyperaceae and Poaceae (Bezerra and França, 1999; França et al., 2003). These lakes are natural aquatic ecosystems and a survey of the anatomical structures of their plants may reveal adaptations to different life forms. Environmental variations contribute to structural changes in the vegetative organs of the aquatic (Wells and Pigliucci, 2000; Burnet et al., 2007) or terrestrial (Moreira and Isaias, 2008) species presenting phenotypic plasticity.

The structural adaptations of the amphibious species of aquatic Cyperaceae from the temporary lakes of the semi-arid region of the State of Bahia include air canals in their vegetative organs, mainly in their roots; a hypoderm; a reduced number of xylem elements; and slightly lignified cell walls in their tissues (Leite et al., 2009).

Given the importance of anatomical studies on macrophyte species for this semi-arid region, this work surveyed the anatomical structures considered as adaptations in some monocot species, taking into account both the emergent (plants are rooted on the bottom of the water and extend to its surface) and amphibious (plants with ability to photosynthesize and grow in terrestrial, as well as aquatic environments) life forms.

\section{Material and Methods}

Specimens of Cyperus odoratus L., Oxycaryum cubense (Poep. \& Kunth) Lye, and Pycreus macrostachyos (Lam.) Raynal (Cyperaceae) - amphibious species - and of Echinodorus grandiflorus (Cham. \& Schltdl.) Micheli (Alismataceae), Eichhornia paniculata (Spreng.) Solms Laubach (Pontederiaceae) and Habenaria repens Nutt. (Orchidaceae) - emergent species - were collected in five temporarily full lakes from the Northeastern semi-arid region of Bahia.

Anatomical analyses were carried out on parts of the vegetative organs of adult plants fixed in FAA 70 (formalin, 70\% ethyl alcohol and glacial acetic acid) for 48 hours and preserved in 70\% ethylic alcohol (Johansen, 1940). The vouchers of the specimens (Cyperus odoratus: Leite et al. 477; Leite 486; Leite and França 495; Leite \& França 519. Oxycaryum cubense: Leite et al. 475; Leite and França 522; Leite and França 523; Leite and França 524; Leite and França 525. Pycreus macrostachyos: Leite 486A; Leite 487A; Leite and França 496; Leite and França 500. Echinodorus grandiflorus: Leite et al. 480; Leite 528; Leite and França 495; Leite and França 517. Eichhornia paniculata: Leite et al. 482; Leite and França 485; Leite and França 498; Leite and França 518. Habenaria repens: Leite et al. 476; Leite and França 483; Leite 487; Leite and Lessa 507) were deposited in the Herbarium of the State University of Feira of Santana (HUEFS), Brazil.

Apical, median and basal regions of roots, rhizomes, leaves and scapes of at least three different individuals of each species were cut. Cross sections were prepared by hand with a blade, colored with safranin and Astra blue (modified from Bukatsch, 1972 apud Kraus and Arduim, 1997) and mounted on semi-permanent slides with glycerin jelly.

Some parts of the vegetative organs were dehydrated in a graded ethanol series and embedded in Leica Historesin ${ }^{\circledR}$ (Feder and O'Brien, 1968). Sections $(10 \mu \mathrm{m})$ were cut on a rotary microtome, stained with toluidine blue (Feder and O'Brien, 1968) and then mounted on permanent slides in Entellan synthetic resin $\left(\right.$ Merck $\left.^{\circledR}\right)$.

\section{Results}

In the macrophytes studied, Cyperus odoratus, Oxycaryum cubense, Pycreus macrostachyos and Echinodorus grandiflorus, Eichhornia paniculata, Habenaria repens, respectively amphibious and emergent species, aeration occurs along the whole plant body. It is determined by the presence of air canals in all the vegetative organs (Figures 1-11,14,18-19,21).

The epidermis of roots, rhizomes, leaves and scapes is single layered in all species, cells with thin walls (Figures 4-14,18-19) or slightly thickened walls and a thin cuticle (Figures 4,6,8). The leaves of the amphibious species Cyperus odoratus, Oxycaryum cubense (Figure 4) and Pycreus macrostachyos and of the emergent species Habenaria repens (Figures 5) are hypostomatic, whereas those of Echinodorus grandiforus and Eichhornia paniculata (Figure 6) are amphistomatic. Cuticles (Ct), which were slightly thickened in the leaf and scape of the amphibious species Cyperus odoratus, Pycreus macrostachyos and Oxycaryum cubense (Figure 4), were only found in the aerial organs.

Air canals are wider in roots than in rhizomes and are located in the cortical region (Figures 1-2,10-11,18-19). In the cortex of the root, air canals of the amphibious species are arranged in parallel to the surface of the organ, as in Cyperus odoratus and Pycreus macrostachyus (Figures 1,10 respectively), however it is transversal to the surface of the organ in the emergent species, as in Echinodorus grandiflorus and Eichhornia paniculata (Figures 2,11 respectively). In the leaves, the air canals (Ac) occupy the central region of the mesophyll (Figure 4). They are wide in most species, albeit smaller in Habenaria repens (Figure 5) and Eichhornia paniculata (Figure 6). 

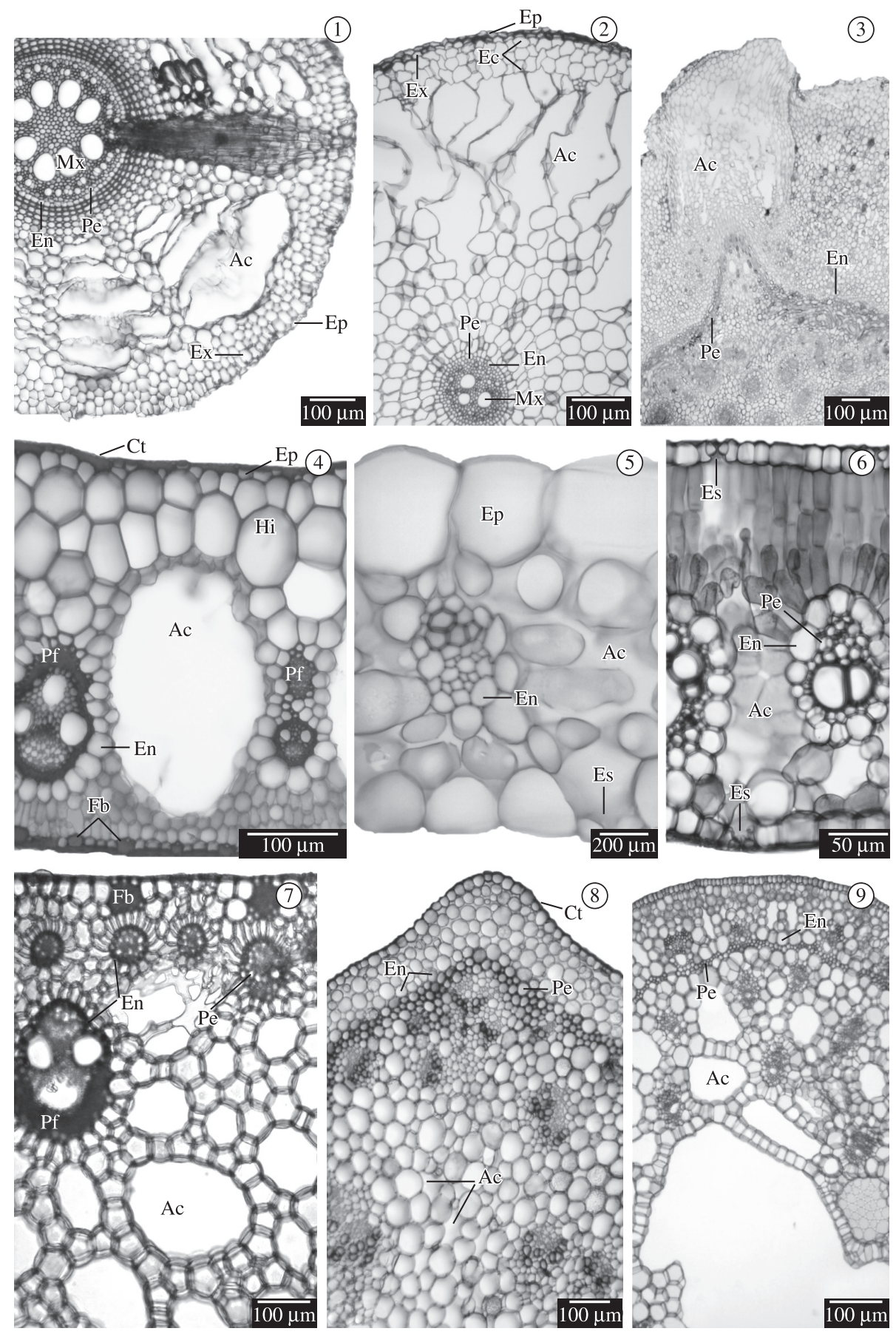

Figures 1-9. Photomicrographs of cross sections of monocot vegetative organs - Median region of roots, rhizomes, leaves and scapes of amphibious and emergent species: 1-2) General aspect of adult roots. 1) Cyperus odoratus. 2) Echinodorus grandiflorus. 3) Cyperus odoratus. - Rhizome. 4-6) Leaves of Oxycaryum cubense, Habenaria repens. and Eichhornia paniculata. 4) Oxycaryum cubense - Detail of air canal. 5) Habenaria repens. - Detail of stoma. 6) Eichhornia paniculata - Detail of stoma. 7-9) General aspect of the scape. 7) Pycreus macrostachyos - Detail of fiber bundles and pericyclic fibers. 8) Habenaria repens. - Detail of pericycle. 9) Eichhornia paniculata - Detail of pericycle. $(\mathrm{Ac}=$ air canals, $\mathrm{Ct}=$ cuticle, $\mathrm{Ec}=$ external cortex, $\mathrm{En}=$ endodermis, $\mathrm{Ep}=$ epidermis, $\mathrm{Es}=$ stoma, $\mathrm{Ex}=$ exodermis, $\mathrm{Fb}=$ fiber bundles, $\mathrm{Hy}=$ hypoderm, $\mathrm{Mx}=$ metaxylem, $\mathrm{Pe}=$ pericycle, $\mathrm{Pf}=$ pericyclic fibers). 

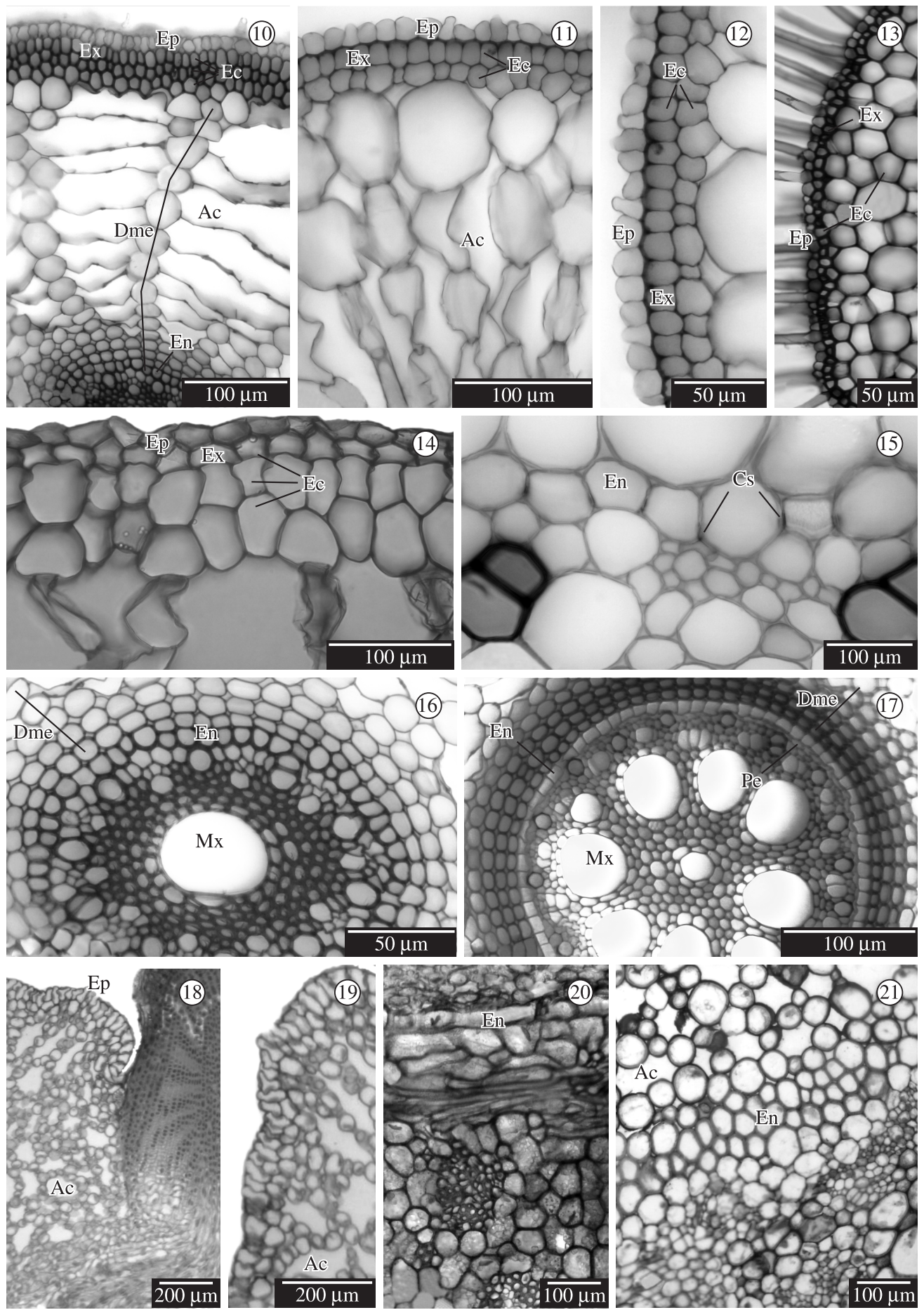

Figures 10-21. Photomicrographs of cross sections of monocot vegetative organs - Median region of roots and rhizomes of amphibious and emergent species: 10-11) General aspect of adult roots. 10) Pycreus macrostachyos. 11) Eichhornia paniculata. 12-14) Detail of exodermis. 12) Eichhornia paniculata.13) Cyperus odoratus. 14) Echinodorus grandiflorus. 15-17) Root endodermis. 15) Habenaria repens. 16) Pycreus macrostachyos. 17) Cyperus odoratus L. 18-20) Rhizome. Echinodorus grandiflorus. 18)General view.19)Detailofepidermis.20-21)Detail of endodermis.20)Echinodorus grandiflorus . 21) Habenaria repens. $(\mathrm{Ac}=$ air canals, $\mathrm{Cs}=$ Casparian strip, Dme $=$ derivatives of meristematic endodermis, Ec $=$ external cortex, $\mathrm{En}=$ endodermis, $\mathrm{Ep}=$ epidermis, $\mathrm{Ex}=$ exodermis, $\mathrm{Fb}=$ fiber bundles, $\mathrm{Mx}=$ metaxylem, $\mathrm{Pf}=$ pericyclic fibers $)$. 
The roots (Figures 1-2,10-11) and rhizomes (Figures 3,18-19) of all studied species presented differentiated cortex and their exodermis (Ex) is formed by a single layer of cells with thickened walls (Figure 1-2, 10-14). The thickening of the external cortex cell walls can be homogeneous as in Pycreus macrostachyos (Figure $10-$ amphibious species), or more intensive in the first cell layer of the external cortex as in Cyperus odoratus (Figure 13 amphibious species), or the internal wall of the exodermal cells can be thinner than the outer periclinal one, as in Eichornnia paniculata and Echinodorus grandiflorus (Figures 11-12,14 - emergent species). In the root cortex (Figures 16-17) and the rhizomes (Figures 20-21), the derivatives cells of the meristematic endodermis (En) present either slightly thickened walls, as in Pycreus macrosctachyos and Cyperus odoratus (amphibious), or more thickened walls, as in Echinodorus grandiflorus and Habenaria repens (emergent species). No wall thickenings were found in the endodermis cells of the roots of Habenaria repens, which present Casparian strips (Figure 15).

All the vegetative organs of the studied species present a low occurrence or absence of supporting tissues. When present, they only occur in such aerial organs as the leaves and scapes of the amphibious species in the form of bundles of sclerenchymatous extravascular fibers (Figure 7) or of vascular pericyclic fibers involving completely the vascular bundles, as in Oxycaryum cubense (Figure 4); they can also form bands of sclerenchymatous pericyclic fibers limiting the vascular cylinder as in the scapes of the emergent species Habenaria repens and Eichhornia paniculata (Figures 8-9). The leaves of Habenaria repens were the only ones that presented no supporting tissue (Figure 5).

All the organs of the studied species, subterranean or aerial, present less conducting elements in their xylem than in their phloem (Figures 5,8,20-21).

\section{Discussion}

In the Brazilian Northeastern semi-arid region, the survival of the aquatic macrophytes from temporary lakes, as is the case of the ones studied here, depends on their tolerance to the excess and lack of water. This tolerance is reflected in adaptations to the aquatic, although temporary, environment as a response manifested by the anatomical, morphological and phenological structures, among others (Wells and Pigliucci, 2000).

Such anatomical features as single layered epidermis and thin cuticle, the presence of air canals, the reduction of supporting tissues and of xylem cells in the plants here studied, regardless of their amphibious or emergent life form, function as adaptations of these species to flood.

The occupation of a one environmental profile by different species of aquatic macrophytes occur by anatomical divergence between their different life forms and anatomical convergence to adapt to the aquatic environment. The disposition of the air canals in the roots of both emergent and amphibious species was considered the most important feature to differentiate the life forms studied in this work.
Although the latter occur in the same area, they are exposed to the same biotic and abiotic factors, and exhibit anatomical convergence, the air canals present in all the vegetative organs are more evident in the emergent species. As observed by Jung et al. (2008), these canals facilitate oxygen conduction to the whole plant body and are considered crucial to the adaptative success of these plants.

Among the existing life forms, emergent and amphibious ones might be the most resistant to water stress since they suffer the seasonality of wet and dry spells, as the species studied here. This resistance may be related to the formation of aerenchyma, an anatomical structure frequent in these species, according to Lewitt (1980) who concluded that lack of oxygen is the main factor inducing the formation of air canals in the roots.

In the aerial organs of the studied species, the formation of air canals may also be linked to the production of oxygen through photosynthesis, as pointed out by Sculthorpe (1967). According to this author, all the gas produced through photosynthesis that is not transported to the subterranean organs accumulates in the intracellular spaces of the aerial organs, favoring their distension.

The presence of only one layer of epidermal cells with a thin layer of cuticle in the aerial organs of the studied species corroborates Sculthorpe (1967) and Matias et al. (2008), who studied other aquatic macrophytes. For them, the presence of a layer of epidermal cells, with an either thin or thick cuticle, will depend on the environmental condition to which plants are submitted.

The number of external cortex cell layers in the roots and rhizomes of the studied species was higher than that of other amphibious species of Cyperaceae, such as Cyperus giganteus (Rodrigues and Estelita, 2003), and of Scrophulariaceae, such as Bacopa salzmanii and Bacopa monnierioides (Bona and Morretes, 2003) but in agreement with Pita and Menezes (2002), the exodermis is single and it is the limitary of external cortex, not having an exodermis plurisseriate. Hypoxia is responsible for the exodermis cell wall thickening (Enstone and Peterson, 2005), common in aquatic plants (Hose et al., 2001).

In most of the aquatic macrophytes studied here, the inner cortex of the roots is derivatives from the meristematic endodermis (Lima and Menezes, 2008; Menezes et al., 2005) and is constituted by various layers of cells with a thickened wall which agree with Williams (1947) and Van Fleet (1961) instead of Sculthorpe (1967), Mauseth (1988) and Seago et al. (2000) who cited that roots and rizomes of aquatic macrophytes living in places subjected to water stress present a strengthened endodermis, usually with more than one cell layer, which was also observed in the species of Cyperaceae from temporary lakes by Leite et al. (2009)

The reduction of the supporting tissues in the different organs of the studied species is common in plants occurring in an environment of lentic water. When compared to those of terrestrial species, such tissues are extremely reduced because these plants do not need any mechanical force to support themselves (Sculthorpe,1967). It is believed that 
the greater quantity of supporting tissues in specimens of Cyperaceae is due to the group genetic information. Whereas Echinodorus grandiflorus, Eichhornia paniculata and Habenaria repens, which belong to distinct taxonomic groups, present a reduction of their supporting tissues as an adaptative response.

When compared to other terrestrial species of the same genus, the reduction of the studied species vascular tissue is related to less numerous conducting elements and thinner cell walls in the xylem, which is an adaptation to aquatic environments (Sculthorpe, 1967; Bristow, 1975; Mauseth, 1988; Bona and Morretes, 2003). Monocots usually have a reduced, poorly lignified vascular system, which leads to the degeneration of some xylem conducting elements without affecting the transportation function (Bristow, 1975).

The anatomical features that confirm the tendency of the adaptive convergence of these plants to temporary lacustrine environments include: single layered epidermal cells with a thin cuticle layer; the presence of air canals in all the organs; a decrease of supporting tissues; a reduction of the number of conducting elements and of the cell wall thickness in the xylem. When compared to the amphibious species, such anatomical features as the reduction of the supporting system, the decrease in number or absence of stomata, less numerous conducting elements and less lignified cells in the xylem were more significant in the emergent species.

Acknowledgements - This work was supported by the Fundação de Apoio à Pesquisa do Estado da Bahia - FAPESB to K.R.B.L. and by the Conselho Nacional de Desenvolvimento Científico e Tecnológico - CNPq (562961/2010-0) to K.R.B.L and (302105/2007-7 and 471202/2008-8) to V.L.S.

\section{References}

BEZERRA, MG. and FRANÇA, F., 1999. Arales de Açudes em uma área do semi-árido baiano. Sitientibus, vol. 20, no. 3, p. 45-54.

BONA, C. and MORRETES, BL., 2003. Anatomia das raízes de Bacopa salzmanii (Benth.) Wettst. Ex Edwall e Bacopa monnierioides (Cham.) Robinson (Scrophullariaceae) em ambientes aquático e terrestre. Acta Botanica Brasilica, vol. 17, no. 1, p. 155-170. http://dx.doi.org/10.1590/S0102-33062003000100012

BRISTOW, JM., 1975. The structure and function of roots in aquatic vascular plants. In TORREY, JG. and CLARK, DT. (Eds.) The development and function of roots. London: Academic Press. p. 221-236.

BURNET, DA., CHAMPION, PD., CLAYTON, JS. and OGDEN, J., 2007. A system for investigation of the temperature responses of emergent aquatic plants. Aquatic Botany, vol. 86, no. 2, p.187-190. http://dx.doi.org/10.1016/j.aquabot.2006.09.015

EITEN, G. and GOODLAND, R., 1979. Ecology and management of semi-arid ecosystems in Brazil. In WALKER, BH. Management of semi-arid ecosystems. Amsterdan: Elsevier Scientific Publishing Company. p. 277-300.

ENSTONE, DE. and PETERSON, CA., 2005. Suberin lamella development in maize seedling roots grown in aerated and stagnant conditions. Plant Cell Environment, vol. 28, no. 4, p. 444-455. http://dx.doi.org/10.1111/j.1365-3040.2005.01286.x
FEDER, N. and O'BRIAN, TP., 1968. Plant microthecnique: some principles and new methods. American Journal of Botany, vol. 55, no. 1, p. 123-142. http://dx.doi.org/10.2307/2440500

FRANÇA, F., MELO, E., GÓES-NETO, A., ARAÚJO, D., BEZERRA, MG., RAMOS, HM., CASTRO, I. and GOMES, D., 2003. Flora vascular de açudes de uma região do semi-árido da Bahia, Brasil. Acta Botanica Brasilica, vol.17, no. 4, p. 549-559.

HOSE, E., CLARKSON, DT., STEUDLE, E., SCHREIBER, L. and HARTUNG, W., 2001. The exodermis: a variable apoplastic barrier. Journal of Experimental Botany, vol. 52, no. 365, p. 2245-2264. PMid:11709575. http://dx.doi.org/10.1093/jexbot/52.365.2245

JOHANSEN, DA., 1940. Plant microtechnique. New York: McGraw Hill Book Co. 523 p.

JUNG, J., LEE, SS. and CHOI, H., 2008. Anatomical patterns of aerenchyma in aquatic and wetland plants. Journal Integrative Plant Biology, vol. 51, no. 2, p. 428-439.

KRAUS, JE. and ARDUIM, M., 1997. Manual básico de métodos em morfologia vegetal. São Paulo: EDUSP. 198 p.

LEITE, KRB., FRANÇA, F. and SCATENA, VL., 2009. Anatomia de espécies anfíbias de Cyperaceae de lagoas do semi-árido, BA, Brasil. Acta Botanica Brasilica, vol. 23, no. 3, p. 786-796. http://dx.doi.org/10.1590/S0102-33062009000300019

LEWITT, J., 1980. Responses of plants to environmental stresses: water, radiation, salt and other stresses. New York: Academic Press.

LIMA, VFGAP. and MENEZES, NL., 2008. Endodermis with meristematic activity in roots of species of Scleria Berg. (Cyperaceae). Boletim de Botânica, vol. 26, p. 1-6.

MALTCHIK, L., COSTA, MAJ. and DUARTE, MDC., 1999. Inventory of brazilian semiarid shallow lakes. Anais da Academia Brasileira de Ciências, vol. 71, no. 4-I, p. 801-808.

MATIAS, LQ., SOARES, A. and SCATENA, VL., 2008. Anatomy of Echinodorus (Alismataceae) scapes from northeastern Brazil as applied to taxonomy. Edinburg Journal Botany, vol. 65, no.1, p. 11-21.

MAUSETH, JD., 1988. Plant anatomy. California: The Benjamin Cumming Publishing Company. 560 p.

MENEZES, NL., SILVA, DC., ARRUDA, RCO., PINNA, GFAM., CARDOSO, VA., CASTRO, NM., SCATENA, VL. and DIAS, ES., 2005. Meristematic activity of the endodermis and the pericycle in the primary thickening in monocotyledons. Considerations on the PTM. Anais da Academia Brasileira de Ciências, vol. 77, no. 2, p.259-274.

MOREIRA, ASFP. and ISAIAS, RMS., 2008. Comparative anatomy of the absortion roots of terrestrial and epiphytic orchids. Brazilian Archives of Biology and Technology, vol. 51, no. 1, p. 83-93. http://dx.doi.org/10.1590/S1516-89132008000100011

PITA, P.B. and MENEZES, NL., 2002. Anatomia da raiz de espécies de Dyckia Schult. f. e Encholirium Mart. Ex Schult. \& Schult. f. (Bromeliaceae, Pitcairnioideae) da Serra do Cipó (Minas Gerais, Brasil), com especial referência ao velame. Revista Brasileira de Botânica, vol. 25, no. 1, p. 25-34.

PIVARI, MOD., SALIMENA, FRG., POTT, VJ. and POTT, A., 2008. Macrófitas aquáticas da Lagoa Silvana, Vale do Rio Doce, Minas Gerais, Brasil. Iheringia, vol. 63, no. 2, p. 321-327.

QUEIROZ, LP., CONCEIÇÃO, AA. and GIULIETTI, AM., 2006. Nordeste semi-árido: caracterização geral e lista das fanerógamas. In GIULIETTI, AM., CONCEIÇÃO, AA. and QUEIROZ, LP. 
(Eds.). Diversidade e caracterização das fanerógamas do semi-árido brasileiro. Recife: Associação Plantas do Nordeste. vol. 1, p. 15-40.

RODRIGUES, AC. and ESTELITA, MEM., 2003. Origin and structure of the kranz tissue in bracts of Cyperus giganteus Vahl (Cyperaceae). Revista Brasileira de Botanica, vol. 26, no. 4, p. $445-452$.

SCULTHORPE, CD., 1967. The biology of aquatic vascular plants. London: Edward Arnold. 610 p.

SEAGO, JL., PETERSON, CA. and ENSTONE, DE., 2000. Cortical development in roots of the aquatic plant Pontederia cordata (Pontederiaceae). American Journal of Botany, vol. 87, no. 8, p. 1116-1127. PMid:10947996. http://dx.doi.org/10.2307/2656648
Van FLEET, DS., 1961. Histochemistry and function of the endodermis. Botanical Review, vol. 27, no. 2, p. 165-221. http://dx.doi.org/10.1007/BF02860082

WELLS, CL. and PIGLIUCCI, M., 2000. Adaptative phenotypic plasticity: the case of heterophylly in aquatic plants. Perspective Plant Ecology, Evolution and Systematic, vol. 3, no. 1, p. 1-18. http://dx.doi.org/10.1078/1433-8319-00001

WILLIAMS, BC., 1947. The sctructure of the meristematic root tip and origin on the primary tissues in the roots of vascular plants. American Journal of Botany, vol. 34, no. 9, p. 455-462. http://dx.doi.org/10.2307/2437260 
